\title{
The Analysis of Vehicle Use Intensity in a Transportation Company
}

\author{
Paweł Droździel ${ }^{1}$
}

${ }^{1}$ Faculty of Mechanical Engineering, Lublin University of Technology, Nadbystrzycka 36, 20-618 Lublin, Poland

\begin{abstract}
Intensity of use is one of the most important parameters of vehicle operation. It is expressed as the number of kilometres travelled by a car within a specified period of time (day, month, or year). The intensity of use affects vehicle life, the costs and the profits from transportation services, drivers' working time, and other parameters of car operation. For that reason, analysis of data associated with the intensity of vehicle use may be instrumental in the evaluation of a given transport system. The paper presents and discusses the results of statistical analyses of data related to the intensity of use of delivery trucks in the Poczta Polska company in Lublin.
\end{abstract}

Keywords transportation company, vehicle usage, statistical analysis

JEL L91, L87, R41

\section{Introduction}

There are numerous indicators used to evaluate and compare the transport system of a transport company. These include profit from transport service, the weight of transported cargo, personnel costs, fuel, lubricating oil, repairs, etc. $[3,4,5]$. However, the intensity of vehicle use remains one of the most important parameters.

It is measured through the number of kilometres travelled by the vehicle over a specific time period (day, month or year). Many other factors and indices depend on the intensity of use: the period of use of a given vehicle, the costs and the profits obtained from the transportation service, driver's working time, as well as other parameters of vehicle operation $[1,6,7,8,9]$.

Therefore, it seems that a thorough analysis of the data related to the intensity of vehicle use is important and helpful in the process of evaluating a given transport system. The paper presents and discusses the results of statistical analysis of the data obtained during the study related to the intensity of use of delivery vehicles of the Poczta Polska (Polish Post Office) in Lublin.

\section{Characteristics of the vehicle fleet used in the transportation company}

The author had the access to the data concerning 179 vehicles that were used in one year in Poczta Polska in Lublin. The studied fleet consisted of vehicles of many makes and types. They performed various transport tasks resulting from the operation and role of the post office. Based on the information obtained from the carrier, the vehicles were divided into three groups with different load capacities.

The group I included passenger vehicles with small load capacity (e.g. Fiat Seicento). The nature of their work involved driving between letterboxes and delivering mail in the city of Lublin and its nearest vicinity. This group comprised 47 vehicles. Group II consisted of delivery vans with an average load capacity (e.g. Lublin III). These vehicles transported mail between post offices in Lublin and the former Lublin Province. This group consisted of 85 cars. Vehicles with large load capacity (e.g. Iveco Stralis) were classified in group III. They were used to transport parcels between logistic centres of Poczta Polska on routes outside the territory of the former Lublin Province. This group included 47 vehicles. 


\section{Results of statistical analyses of the in- tensity of vehicle use}

The data on the intensity of vehicle use acquired from Poczta Polska in Lublin were statistically analysed using the Statistica PL software package. The results for the whole fleet of the studied vehicles as well as for the groups of vehicles are presented in Table 1.

Table 1. Position and scatter parameters of the annual intensity of vehicle use in the studied transport company

\begin{tabular}{|c|c|c|c|c|c|c|}
\hline \multirow{4}{*}{ Group } & $\begin{array}{c}\text { Mean } \\
\text { value }\end{array}$ & Median & $\begin{array}{c}\text { Min. } \\
\text { value }\end{array}$ & $\begin{array}{c}\text { Max. } \\
\text { value }\end{array}$ & $\begin{array}{c}\text { Standard } \\
\text { deviation }\end{array}$ & $\begin{array}{c}\text { Standard } \\
\text { error }\end{array}$ \\
\cline { 2 - 7 } & $l$ & me & & & $\sigma_{1}$ & $\delta_{1}$ \\
\cline { 2 - 7 } & {$[\mathrm{km} /$ year] $]$} & {$[\mathrm{km} /$ year] $]$} & {$[\mathrm{km} /$ year] $]$} & {$[\mathrm{km} /$ year] } & {$[\mathrm{km} /$ year $]$} & {$[\mathrm{km} /$ year] } \\
\hline Group I & 14437 & 12144 & 1248 & 46511 & 8432 & 1230 \\
\hline Group II & 34762 & 35315 & 67 & 97707 & 17716 & 1922 \\
\hline $\begin{array}{c}\text { Group } \\
\text { III }\end{array}$ & 83597 & 87771 & 3515 & 164244 & 48239 & 7036 \\
\hline $\begin{array}{c}\text { Groups } \\
\text { I, II and } \\
\text { III }\end{array}$ & 42248 & 30316 & 67 & 164244 & 38082 & 2846 \\
\hline
\end{tabular}

Figure 1 and Figure 2 shows the statistical histograms for the annual intensity of vehicle use.
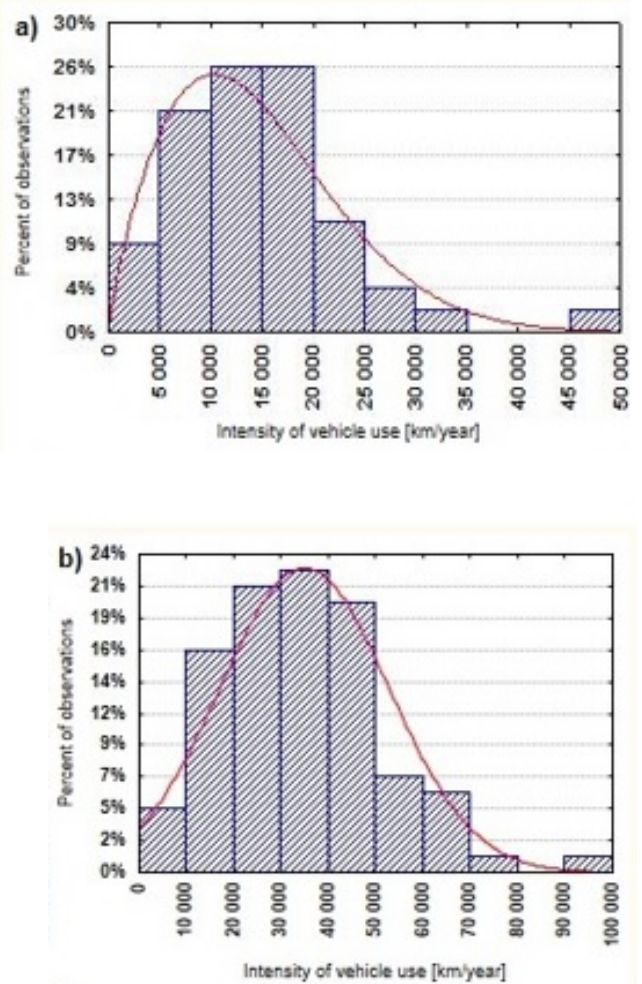

Figure 1. Statistical distribution of annual intensity of vehicle use; (a) group I density function fit to empirical data by Weibull distribution (significance level $\mathrm{p}<0.01$ ) with scale parameter: 16225.25 and shape parameter: 1.796 , (b) group II density function fit to empirical data by normal distribution (significance level $\mathrm{p}<0.01$ ) with position parameter: 34761.98 and scale parameter: 17716.66 .
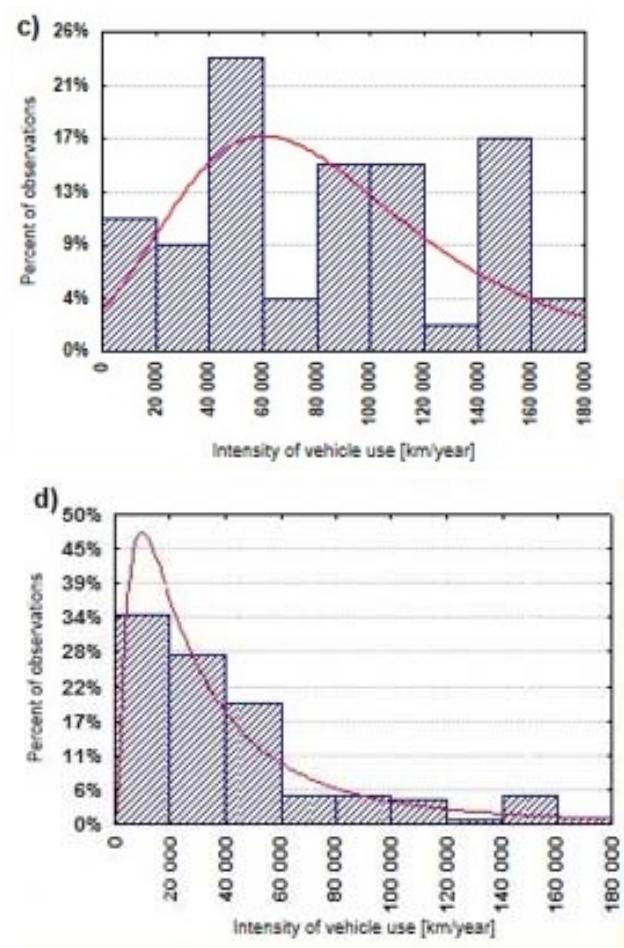

Figure 2. Statistical distribution of annual intensity of vehicle use; (c) group III density function fit to empirical data by extreme value distribution (significance level $\mathrm{p}<0.01$ ) with position parameter: 59936.11 and scale parameter: 42740.60 , (d) all vehicles density function fit to empirical data by lognormal distribution (significance level $\mathrm{p}<0.01$ ) with scale parameter:10.24 and shape parameter: 1.04

While discussing the distributions from Figures 1 and 2, it should be stated that the annual intensity of vehicle uses in group I does not exceed $10,000 \mathrm{~km} /$ year in $30.2 \%$ of the observed cases. The mileage up to $20,000 \mathrm{~km} /$ year occurs in almost $82 \%$. For group II, mileages up to $20,000 \mathrm{~km} /$ year occur in $21 \%$, and up to $40,000 \mathrm{~km} /$ year in $64.2 \%$ of cases. For group III, mileage up to $20,000 \mathrm{~km} /$ year constitutes only $11 \%$ of the cases. In this group, $43.6 \%$ of observations the annual intensity does not exceed 60 thousand $\mathrm{km} / \mathrm{year}$. For group III, the share of the annual mileage exceeding 140,000 km/year is significant $(21.1 \%)$.

When analysing the results of the calculation of statistical parameters presented in Table 1, attention should be paid to the differences occurring between the values of the average annual intensity of use in individual groups of vehicles. To check whether the observed differences are statistically significant, an analysis of variance was performed.

Its first step is to check whether the empirical data can be approximated by a normal distribution. As it can be seen from Figures 1 and 2, the histograms of the annual intensity of vehicle use for groups I and III cannot be fitted by a normal distribution. This was also confirmed by the analysis performed using the chi-square $\chi 2$ test. Additionally, the occurrence of variance heterogeneity in individual vehicle groups was found. The Bartlett's B test [2] was applied (because of a non-uniform number of objects in the analysed groups). The value of the test statistic was $\mathrm{B}=134.48$ at the significance level of $p=0.001$. 
Failure to meet the assumptions about the normality of the distribution of the analysed variable and the heterogeneity of the variance made it impossible to apply the method of classical analysis of variance to the observed annual values of vehicle use intensity. Therefore, in further calculations, the non-parametric method of analysis of variance using the Kruskal-Wallis K-W test [2] was applied. The calculations showed that the value of the statistic is $\mathrm{K}-\mathrm{W}=80.145$ with a significance level of $\mathrm{p}=0.001$. This result indicates that there is a significant difference between the mean value of the annual intensity of vehicle use in particular groups.

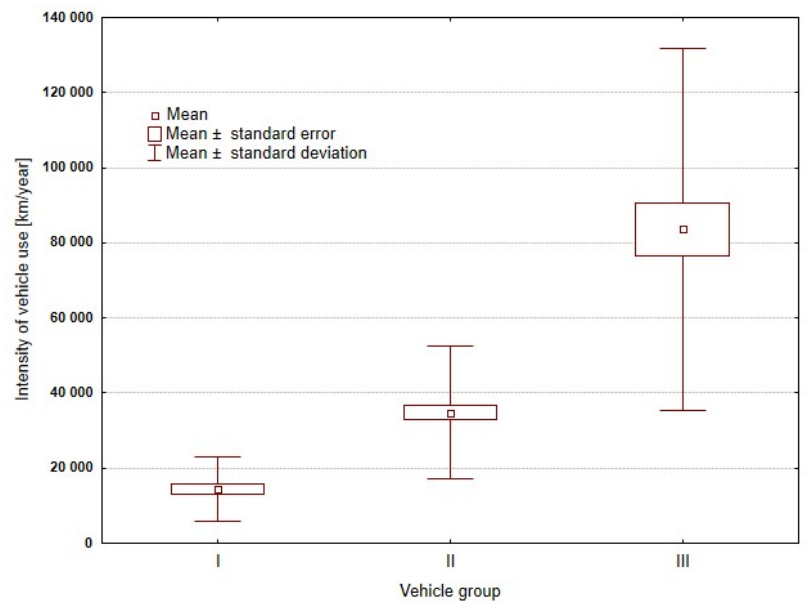

Figure 3. Categorized box plot for the independent factor, i.e. vehicle group and the dependent variable, i.e. annual vehicle use intensity

Figure 3 presents a categorized box plot for the annual intensity of use depending on the distinguished group of vehicles. The observed occurrence of differences for the average value of the annual intensity of use between the groups of vehicles results from the nature and scope of the transport work performed.

In further analyses, it was checked whether the month (as a grouping factor) has a significant effect on the average value of the monthly intensity of vehicle use in individual groups. The calculations carried out using the chi-square $\chi 2$ test showed the conformity of the distributions of the mean monthly intensity of vehicle use in individual groups with a normal distribution. Homogeneity of variance was also checked using the Bartlett B test [2]. The obtained results are presented in Table 2.

Table 2. Bartlett's test results for homogeneity of variance for vehicle use intensity for the grouping factor - month of operation

\begin{tabular}{|c|c|c|}
\hline Group & Statistic B & $p$ value \\
\hline I & 6.80 & 0.814 \\
\hline II & 5.12 & 0.925 \\
\hline II & 4.56 & 0.950 \\
\hline
\end{tabular}

The results pertaining to the homogeneity of variance for monthly usage intensity in each vehicle group presented in Table 2 indicated that the classical analysis of variance method could be applied. The results of the calculations performed using the Fisher F test are presented in Table 3.
Table 3. Results of the analysis of variance for the factor grouping month of operation

\begin{tabular}{|c|c|c|}
\hline Group & Statistic F & $p$ value \\
\hline I & 1.567 & 0.104 \\
\hline II & 1.392 & 0.170 \\
\hline II & 1.698 & 0.071 \\
\hline
\end{tabular}

The obtained results presented in Table 3 allow stating that the month of operation (as a grouping factor) does not significantly affect the value of the observed average monthly intensity of vehicle use. This is confirmed by the categorized box plots presented in Figure 4 for the monthly intensity of use in each group of vehicles.
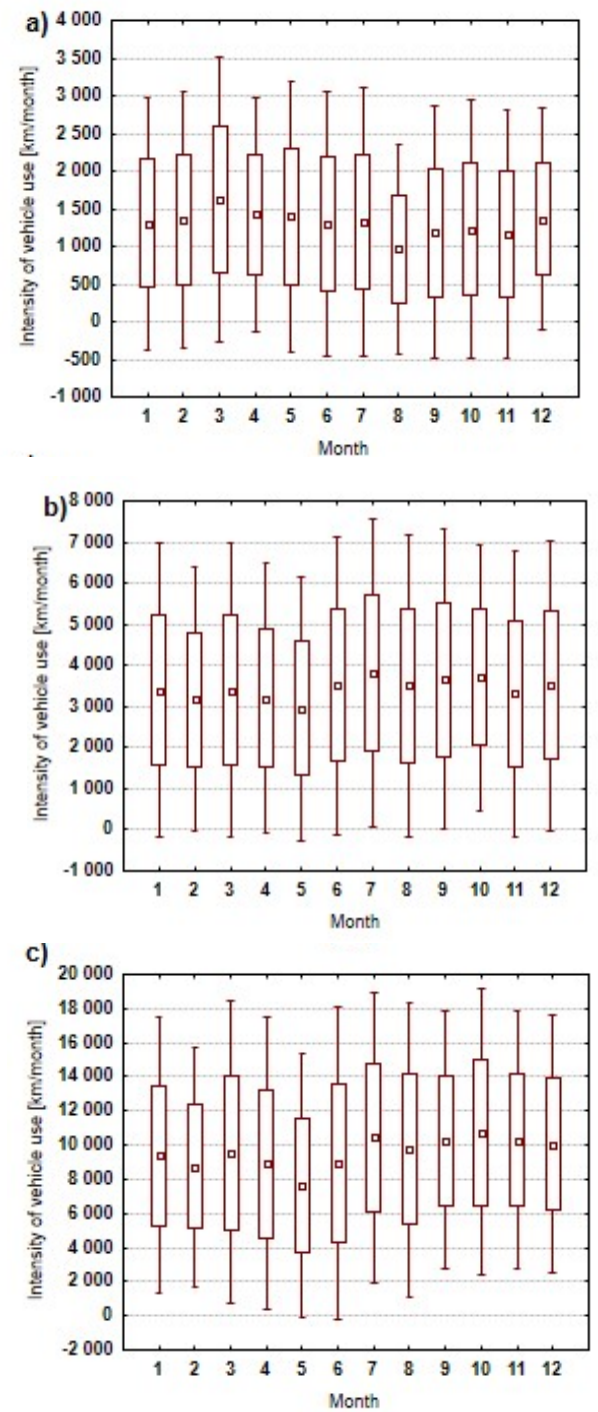

Figure 4. Categorized box plot for the independent factor, i.e. month and the dependent variable, i.e. monthly vehicle use intensity; (a) group I, (b) group II, group III

\section{Conclusions}

The obtained results of statistical analyses performed and discussed in the article for the data related to the intensity of 
use of vehicles of the Poczta Polska in Lublin allow drawing the following conclusions:

1. The division of the vehicle population into three groups based on the size of the cargo space is correct. It is indicated by significant differences between particular groups for average values of annual and monthly intensity of vehicle use.

2. In group II, the values of the average annual intensity of vehicle use were almost 2.5 times higher than those observed in group I. A similar proportion occurred also for the intensity of vehicle use of group III, relative to group II.

3. Month of operation has no significant effect on the observed values of the average monthly intensity of vehicle use in particular groups.

The obtained results indicate that the vehicles perform transportation according to a well-defined travel plan. This allows concluding that decision-making related to transportation routing in Poczta Polska is a properly executed process.

Finally, it should be added that the statistical analyses were conducted for the information related to the process of vehicle operation for one year. Therefore, it cannot be determined unequivocally whether there is the repeatability of the results for the observed values of vehicle utilization intensity in other years. For this purpose, similar calculations should be performed for the data from at least several years of vehicle operation in each transportation company. The authors hope to carry out further research on this topic in the future.

\section{REFERENCES}

[1] Droździel P., Krzywonos L.: A model of the economic effectiveness of the truck transportation services, Transport Problems, vol. 5 issue 4, Gliwice, Wyd. Politechniki Śląskiej 2010.

[2] Dobosz M.: Wspomagana komputerowo statystyczna analiza wyników badań. Wydawnictwo, Warszawa, EXIT 2004.

[3] Hebda M.: Eksploatacja samochodów, Radom, Wyd. ITE PIB 2005.

[4] Mendyk E.: Ekonomika transportu, Poznań, Wyd. WSL. 2009

[5] Rydzykowski W., Wojewódzka-Król K.: Transport, Warszawa, PWN 2009.

[6] Smalko Z.: Podstawy eksploatacji technicznej pojazdów, Warszawa, Wyd. Politechniki Warszawskiej 1998.

[7] Woropay M., Landowski B., Jaskulski Z.: Wybrane problemy eksploatacji i zarządzania systemami technicznymi. Bydgoszcz, Wyd. Uczelniane Akademii Techniczno-Rolniczej w Bydgoszczy 2004.

[8] Madlenak, R., Madlenakova, L., Stefunko, J.: The variant approach to the optimization of the postal transportation network in the conditions of the Slovak republic. Transport and Telecommunication Journal, 16(3), 2015, pp. 237-245. doi:10.1515/ttj-2015-0022

[9] Madlenak, R., Madlenakova, L.: Comparison of Regional Postal Transportation Networks in Zilina Region. In Transport Means 2015, Pts I and II, 2015 (pp. 277-280). 